\title{
Influence of economic freedom and its subcomponents on risk-taking behavior
}

\section{Evidence from dual banking system of Malaysia}

\author{
Rafik Harkati, Syed Musa Alhabshi and Salina Kassim \\ IIUM Institute of Islamic Banking \& Finance (IIiBF), \\ International Islamic University Malaysia, Kuala Lumpur, Malaysia
}

Received 10 September 2019

\begin{abstract}
Purpose - The purpose of this paper is to investigate the influence of economic freedom and six relevant subcomponents of it on the risk-taking behavior of banks in the Malaysian dual banking system. It also aims to make a comparative analysis between Islamic and conventional banks operating in this dual banking sector. Moreover, the study is an effort to enrich the existing literature by presenting empirical evidence on the argument that the risk-taking behavior of the two types of banks is indistinguishable given that they operate in the same regulatory environment.

Design/methodology/approach - Secondary data of all banks operating in the Malaysian banking sector are collected from FitchConnect database, in addition to the economic freedom index from Foundation Heritage for the period 2011-2017. Generalized least squares technique is employed to estimate the influence of economic freedom and the six relevant subcomponents of it on the risk-taking behavior of banks.

Findings - The level of economic freedom influenced risk-taking behavior within the banking sector as a whole, conventional and Islamic banking sectors negatively during the study period (2011-2017). Risk-taking behavior of conventional and Islamic banks is similar. However, conventional banks turn to be less influenced by economic freedom level as compared to Islamic banks.

Practical implications - The government and regulators may benefit from the results by rethinking and setting the best economic freedom index that better serves the stability of the banking system, and lessens banks' risk-taking inclination.

Originality/value - To the present time, this paper is thought to be of a significant contribution. Given the argument that Islamic and conventional banks behave in the same way. This is one of the first attempts to address this issue in light of the influence of economic freedom and six subcomponents of it on the risk-taking behavior of banks operating in a dual banking system.
\end{abstract}

Keywords Islamic banks, Conventional banks, Economic freedom, Economic freedom subcomponents,

Risk-taking behaviour

Paper type Research paper

\section{Introduction}

Economic freedom index is an indicator that represents how relaxed a country's policies in the eye of participants within a particular economy. It comprises ten components, namely, trade, capital flows and foreign investment, government interventions, banking and finance, monetary policy, property rights, government finances, wages and prices and regulation, in addition to black market activity. Being made up of several components, the economic freedom index embodies the main policy and institutional areas of a country; this obviously determines a significant role for governments. Higher scores of the index reflect favorable polices to contestability and the economy at large. To the point where freedoms permit banks to reinforce efficiency and engage in different activities and diversify their risks, it is anticipated that the elevated level of freedom results in a robust economy. However, higher economic freedom scores pave the way for banks to undertake risky activities, in particular when the institutional environment and existing regulations and supervision deform motives of risk-taking. Therefore, too much freedom could render banks dysfunctional. Beck et al. (2006) maintain that countries with considerable freedoms in the banking industry and 
$\mathrm{RBF}$

12,4

aggregately more contestable economic policies are less probable to undergo banking crises. Nevertheless, these policies tend to relax entry barriers, in addition to being associated with decreasing levels of concentration in the industry.

By virtue the Shariah principle, usury (Riba or interest rate), uncertainty (Gharar), gambling (Qimar) and deception (Maysir) are strictly prohibited to be part of an Islamic product (Iqbal and Mirakhor, 2007); this implies the possibility that Islamic banks may be inclined to assume higher risks and likely to bring about risk concentration (Sundararajan and Errico, 2002). Islamic banks also encounter the problem of short-term asset liability mismatches that attributes to constraints on the money market instruments they are allowed to use. Consequently, regardless of the fact that the environment for economic freedom is the same for conventional and Islamic banks, restrictions on both assets and liabilities sides could control their risk-taking appetite. Nevertheless, Akthar Aziz (2009) argued that the tied linkage between financial transactions and productive flows implied in Islamic finance was effective in protecting them from the negative consequences of the 2007-2009 financial crisis. In support of this, Sufian and Zulkhibri (2011) reported that economic freedom influences the performance of Islamic banks positively. Accordingly, Islamic banks could be more risk-taking inclined as compared to their conventional counterparts.

The main purpose of the present paper is to add to the earlier literature on banks risk-taking, particularly for emerging economies in terms of establishing empirical evidence on the role of economic freedom and its subcomponents relevant to the financial aspect in determining the risk-taking behavior of conventional and Islamic banks operating in the same regulatory environment. Since the research is limited to the Malaysian banking system context, a dual banking system, this allows making a comparison between two different systems, namely conventional and Islamic in light of how their risk-taking is influenced by the level of economic freedom and the relevant subcomponents. Up to the present time, the influence of economic freedom and its subcomponents on risk-taking of banks has not been investigated sufficiently. For a dual banking system, this is the very first attempt to address this gap as a comparative analysis between conventional and Islamic banks.

This study is of great importance not only for the government as it is the main controller of the level of its economic openness but also for banks being the major controller of financial flows as they hold a percentage exceeding 70 of the financial system in Malaysia. It goes without saying that the linkage between banking sector soundness and growth of the economy is very decisive; therefore, the banking sector's health is crucial. In addition, investigating the role of economic freedom and its relevant subcomponents in determining the risk appetite of banks is significant for the government, policy makers and regulators.

The remaining of the paper is arranged as follows. Section 2 presents a literature review, which commences with an overview of the market structure change in Malaysia, and then it sheds light on the literature pertinent to the influence of economic freedom and its relevant subcomponents to the financial aspect of the risk-taking of banks. Section 3 is on data and variables, followed by Section 4, methodology. Section 5 provides comprehensive discussions of the results as well as a comparison between Islamic and conventional banks' risk-taking. Lastly, concluding remarks and policy implications are in Section 6.

\section{Literature review}

\subsection{Market structure change in the Malaysian banking sector}

The banking industry in Malaysia has undergone an accelerating liberalization process, this surge, in turn, led to a quick expansion in business reflected in the immense increase in the portfolio of loans as well as operations. Given the robust principles and the huge local demand within the banking sector of Malaysia, the banking industry assisted banks in getting their operations expanded toward foreign financial markets regardless of the negative indirect effects of the US subprime crisis (Saiti et al., 2016). 
For motivating mergers of small-sized local banks, in the 1990s a two-tier banking system was introduced by Bank Negara Malaysia (BNM), this marked the onset of consolidation in the Malaysian banking sector (Bank Negara Malaysia, 1999). Nevertheless, this initiative did not work out, as a few mergers were carried out to capitalize on the advantages of tier-one banking group status (Sufian, 2007). There were only three banking mergers given the tier-1 institutions status: DCB Bank with Kwong Yik Bank[1], DCB Finance with Kwong Yik Finance and United Overseas Bank with Chung Khiaw Bank, resulting in both DCB Bank and Kwong Yik Bank granted the tier-1 institutions status[2]. Sufian (2007) stated that the smaller banks with the tier-2 status had increased their capital to gradate to tier-1 status. Furthermore, to guarantee enough return on capital, considerable tier-2 banks have been lending unwisely and, as a result, endured huge losses throughout the Asian financial crisis (Sufian, 2007). In the aftermath of the 1997 Asian financial crisis, and in order to scale down the likely effects of systemic banks upon the banking sector, tight measures were adopted to compel incorporated local banks to merge (Bank Negara Malaysia, 1999). Consequently, a further merger plan was introduced where local banking institutions were demanded to form their merger and point a leader (Bank Negara Malaysia, 1999). In response to this plan, ten domestic banking groups were granted acceptance. In spite of this, BNM stated that it would still take part directly to single out partners if banks do not manage to accomplish the mergers. Ten anchor banks were chosen, each bank possessed minimum shareholders' funds of RM2bn and an asset base of at least RM25bn (Bank Negara Malaysia, 1999). The number of local banks declined considerably as a result of establishing these ten banking groups to only 29 banking institutions, ten finance companies, ten commercial banks and nine merchant banks. The banking sector of Malaysia has seen a considerable market structure change in the aftermath of the consolidation process of the banking sector. In this regard, the consolidation process is marked as a structural amendment of the local banking sector. The number of banks dropped after the consolidation process, whereas the market concentration augmented considerably. The Malaysian banking sector consolidation is mainly marked by horizontal mergers among banks, this in turn gave rise to overlapping market partition. In addition, the process has led to the creation of many chief banks and/or financial holding companies, and therefore a broad distribution of bank size.

The financial landscape in Malaysia has witnessed a dramatic change. Malaysia has successfully implemented a dual banking system and has set itself as the forerunner country to adopt a full-fledged Islamic system running alongside the conventional banking system. Islamic banking has gained its importance and has been on an advanced upward trend. Starting from 2005, the Islamic banking industry has experienced an annual growth, at an average rate, of 18.8 percent in terms of assets, 12.1 percent in terms of financing, and 18.2 percent in terms of deposits (Bank Negara Malaysia, 2016). Based on Table I, the number of players in the Malaysian banking system landscape has experienced some changes. The number of commercial banks declined from 27 to 22 in the year 2006, then it remained constant until the year 2010 where it increased to 23 participants, 25 in the year 2011, after that, namely from the year 2012-2017 the number was stable at 27 commercial banks. For investment banks, it has witnessed an increase of five participants, then it decreased throughout the period 2012-2017 to just ten players. On the other hand, Islamic banks increased from six participants in the year 2005 to 17 participants by the year 2017. This increase in the number of Islamic banks is due to the introduction of Islamic banks' subsidiaries as well as allowing foreign banks to participate in the Malaysian banking system. This signifies that Islamic banks' market share has considerably increased in the Malaysian banking system, which in turn has implications in terms of competition and concentration.

Even though the number of empirical studies on concentration in the banking sector has seen an increasing trend recently, it is still relatively scarce, particularly in the countries that 


\begin{tabular}{|c|c|c|c|c|}
\hline \multirow{5}{*}{$\begin{array}{l}\mathrm{RBF} \\
12,4\end{array}$} & Year & Commercial banks & Investment banks & Islamic banks $^{\mathrm{a}}$ \\
\hline & 2005 & 27 & 10 & 6 \\
\hline & 2006 & 22 & 10 & 10 \\
\hline & 2007 & 22 & 14 & 11 \\
\hline & 2008 & 22 & 15 & 17 \\
\hline \multirow{8}{*}{338} & 2009 & 22 & 15 & 17 \\
\hline & 2010 & 23 & 15 & 17 \\
\hline & 2011 & 25 & 15 & 16 \\
\hline & 2012 & 27 & 13 & 16 \\
\hline & 2013 & 27 & 12 & 16 \\
\hline & 2014 & 27 & 11 & 16 \\
\hline & 2015 & 27 & 11 & 16 \\
\hline & 2016 & 27 & 11 & 16 \\
\hline $\begin{array}{l}\text { Table l. } \\
\text { Change in the }\end{array}$ & 2017 & 27 & 10 & 17 \\
\hline
\end{tabular}

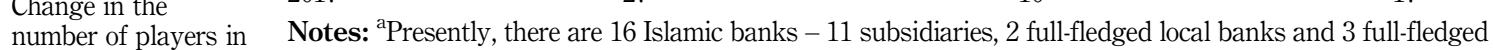
the Malaysia banking sector foreign banks (Ibrahim et al., 2019)

Source: Bank Negara Malaysia (2016)

adopt a dual banking system. To this end, the sub-objective of this study is to investigate concentration conditions in the dual banking system of Malaysia to provide evidence on two banking systems coexisting in the same environment. Especially after the Islamic banking sector has witnessed considerable growth and development in Malaysia, where it has been gaining more market power in the face of the fierce competitive conventional sector. In contrast, previous studies (Majid and Sufian, 2007; Fah and Ariff, 2017; Ibrahim et al., 2019) have investigated concentration focusing on the entire banking sector along with the conventional sector, or they have focused on commercial banks or the ten largest banks in the banking industry. In addition, other studies have focused on one sector only, i.e., Islamicsector (Majid and Sufian, 2007; Mohammed et al., 2015), conventional sector (Gajurel and Pradhan, 2012; Sharma and Bal, 2010). Although there are studies that used concentration measures to measure competition (Hakim and Chkir, 2014) and that examined both the banking system (Uddin and Suzuki, 2014), comparative studies that took into consideration both banking systems are still limited, particularly for an emerging economy like Malaysia.

\subsection{Economic freedom and the banking system in light of risk-taking behavior}

Knight (1921) was one of the earliest authors to give a definition to risk-taking; he was the first to coin a precise definition of risks and uncertainties. He defines risk and risk-taking as follows: "Risks and risk-taking are two co-related while relatively independent concepts. The core proposition of enterprise decision making is how to maximize the values under the condition of limited internal resources. At the same time companies have to face external uncertainties, which may bring either benefits or losses." Schonberg et al. (2011) define risk as the exposure to negative outcomes, or/and the variations of outcomes due to the undertaken decision.

A prominent measure for countries' policies ranking is an economic freedom index. Information on this index can be obtained from The Heritage Foundation. Values of the index indicate how liberal or stringent an economy is, with an elevated score representing a highly free economy and suitability for contestability. Furthermore, as a part of the index, banking freedom does not include as much information as those contained in economic freedom. Banks are free at a point where they can pursue different activities as well as diversifying their risks; we anticipate an elevated score to enhance banking stability through relaxed constrains. However, it is true that a high score indicates that banks are inclined to take higher risk, in particular, if the institutional sphere, regulations and supervision deform risk-taking motives. Soedarmono et al. (2013) in addition to results 
pertinent to other variables showed that economic freedom and stock market capitalization do not necessarily hinder the degree of market power in the banking industry. Specifically, both factors positively impact the degree of market power in the banking industry. Beck et al. (2006) maintain that elevated freedoms in banking sector - in other words, more contestable economic policies - are less probable to bring about banking instability.

Economic freedom and its impact on risk-taking of banks have not been investigated extensively in the previous studies related to risk-taking. The subtle point that has not been sufficiently unveiled is whether and how economic freedom is related to bank risk-taking, particularly in a dual banking system. Index of economic freedom is made up of a variety of components; therefore, it mirrors major institutional and policy areas of a given country, this apparently reflects a significant role for the government. In this regard, one issue that widely draws the attention is the linkage between economic freedom, especially its subcomponents related to the financial aspect and risk-taking appetite of banks. From the financial perspective, the rationale for the hypothesized linkage between financial freedom (FF) and risk-taking of banks is not clear, a priori. In contrast, the lenient restrictions encountered by financial institutions on how to handle their business, most probabily they will adopt risks proportionate with their risk appetite; however, higher freedom may give rise to high risk-taking. Following the financial suppression argument of McKinnon-Shaw, deep government intervention can constrain the free competition of market forces and restrain bank innovative activity (e.g. novel products and services). Consequently, banks may be tempted to accept higher risks so that they compensate for decreasing margins. The statements for economic freedom give rise to alleviation in bank risk-taking are no less persuasive. Kim and Santomero (1988), for instance, have noticed that the linkage between risk-taking and capital could be negative. In such a situation, despite the fact that the levels of economic freedom may be high, risk-averse banks with high capital levels may be less motivated to take on higher risks. Similarly, if the banking system is already over-extended, regulators could impose "speed limits" on credit growth (Honohan, 2000), so that even with elevated economic freedom, risk inclination may not be proportionally high.

The relationship between economic freedom and behavior of a wide range of variables has been conducted sufficiently in literature at two levels, namely individual country level as well as the cross-national level. Country case-based research proposesthat overall economic freedom places a positive impact on the profitability of Chinese banks (Sufian and Habibullah, 2010). On the other hand, considering cross-national samples, Carey and Stulz (2006) report that economic freedom makes banks able to enhance levels of efficiency. De Haan and Sturm (2003) investigate the implications of crises on economic freedom in a case study for Norway and Sweden, employing cross-country regressions. They offered evidence to behold that economic freedom declines after a crisis but increases afterwards. Sufian and Hassan (2012) examine the implications of economic freedom for banks' intermediation costs for ASEAN countries during 1994-2008. They concluded that economic freedom enhances the environment accompanied by entrepreneurship and innovation and as a sequence places a positive effect on sustainable economic development. Utilizing data for the period 1976-2008, Baier et al. (2012) stated that a one-unit rise in the overall index of economic freedom is accompanied with about three percentage points decrease in the likelihood of banking crises occurrence. These studies motivated us to look into the manner economic freedom and its relevant subcomponents exert influence on the risk-taking behavior of both Islamic and conventional banks in a dual banking system (banks operating in the same economic environment).

Economic Freedom (ECOFREE) is one of the tool variables for LERNER rather than the Banking Freedom indicator employed by Berger et al. (2009), given that the Economic Freedom index made up of a wider collection of economic openness measures compared to the Banking Freedom index. ECOFREE is a composite index of ten indicators ranking policies in the areas of trade, government finances, government interventions, monetary 
$\mathrm{RBF}$

12,4

340

policy, capital flows and foreign investment, banking and finance, wages and prices, property rights, regulation and black market activity. The index ranges from 0 to 100 with greater scores showing policies being more favorable to competition and economic freedom. Soedarmono et al. (2013) stated that economic freedom and stock market capitalization (stock) do not necessarily curb the level of market power in the banking industry. Particularly, both economic freedom and stock positively affect the level of market power (competition) in the banking sector.

The index of economic freedom generally comprises ten constituents assorted into four wide groups: Rule of Law; Limited Government; Regulatory Efficiency and Open Markets. It is scored on a scale of $0-100$, where 100 implies the absolute freedom; free 80-100; mostly free 70-79.9; moderately free 60-69.9; mostly unfree 50-59.9; and repressed $0-49.9$. The Malaysian economic freedom score is 74.5, setting the Malaysian economy the 22nd freest in 2018. However, its score has declined by 0.7 point, with higher scores for trade freedom and fiscal health offsetting a decrease in the business freedom indicator. In the Asia-Pacific region Malaysia is classified 6th among 43 countries, and its overall score is higher than the regional and world averages. In its report (2018), the Institute for Democracy and Economic Affairs (IDEAS) commented on Malaysia's decline in the classification from 65 to 79 for the current year out of 162 countries, covered in the annual report issued by Canada's Fraser Institute. IDEAS Chief Executive Ali Salman said even though the classification was constructed relying on 2016-2017 data, the classification presented how the private sector had been "squeezed," businesses hampered and share of the government augmented. This sharp decline raises a very critical question, Is it imperative to review the Malaysian economic policies? In this study, we address this in light of banks' risk-taking to figure out whether high economic freedom curbs banks' motivation to engage in risky activities.

"Where people are free to pursue their own opportunities and make their own choices, they lead more prosperous, happier and healthier lives," said Fred McMahon, Dr Michael A. Walker Research Chair in Economic Freedom with the Fraser Institute (Syahirah, 2018). It is understood that high economic freedom leads to a more prosperous economy at large. However, economic freedom means the easy entry of new rivals into the local economy, which in turn fuels competition and thereby causes concentration to shrink due to the increase in the number of players. Economic freedom's impact on the banking sector in terms of risk-taking has not been addressed within the banking sector of Malaysia. Thus, in this study, we shed light on the implication of economic freedom and some of its relevant subcomponents on both Islamic and conventional banks risk-taking. We aim to look into the response of the two types of banks to change in the level of economic freedom and its six relevant subcomponents.

Figure 1 shows that economic freedom in Malaysia has been on a rising trend. However, the global ranking has experienced a decline of 14 positions; this implies that businesses have been hindered and government intervention increased.

\subsection{Economic freedom index components and bank risk-taking}

In addition to the general index of economic freedom, this study considers six subcomponents, namely five related to financial activities, whereas the sixth reflects government integrity. This is to figure out which subcomponent turns to be of a great contribution to the determination of banks' risk-taking.

Business freedom reflects the right of individuals or entities to set up and conduct business without encountering much intervention from the government. Heavy and excessive regulation imposed by the state is among the most common impediments to conduct business activities freely. The higher the business freedom score, the lower the regulation burden individual and business entities have to endure - in other words, lower cost of outputs. The business environment is easy to predict in an environment where business freedom is high in terms of productivity and profitability. In other words, where regulation is not burdensome 


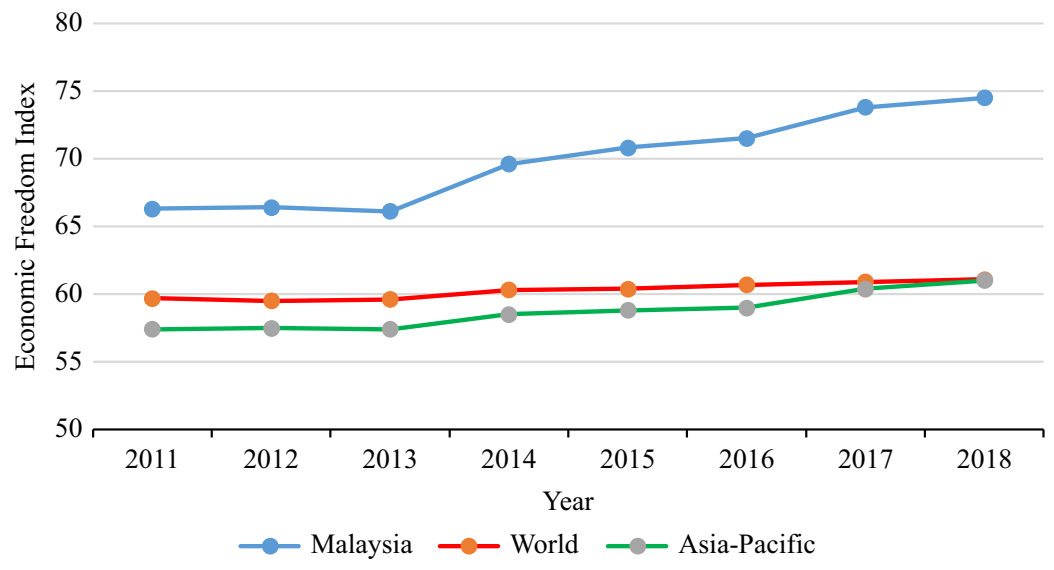

Source: www.heritage.org

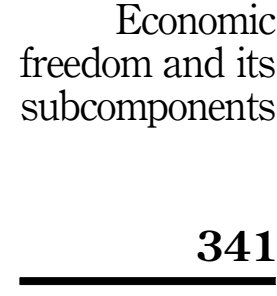

Figure 1. Malaysian economic freedom index

and obtaining a license for a new business is effortless and costless. Nevertheless, in an open economy the government only intervenes in certain necessary matters such as typical decision-making or price-setting procedure (Heritage Foundation, 2016). Intuitively, governments constraints imposed on business activities could induce corporates to promote their risk-taking by extending more loans (increasing loan portfolio riskiness) in order to maintain intermediation margins or boost their market share.

Monetary freedom necessitates the stability of the country's currency as well as market-determined prices. A stable currency is as vitally important for entrepreneurs as it is for consumers. A reliable currency is a key to long-term value and accumulative capital. It is taken as a given that the currency of any given country is crucially affected by its monetary policy. A sound monetary policy that leads to stable prices, maintain inflation within reasonable boundaries and safe the wealth of the country makes it easy and possible for people to accurately predict their plans with regard to investments and savings. In contrast, adopting an inflationary policy could lead to burdensome consequences embodied in invisible taxes and instable prices, elevated costs of conducting business, misallocation of resources and therefore diminishing the wealth of the country. There is not an ideal monetary policy agreed upon. Presently, low inflation and independency of the central banks are desired, in addition to the widespread notion that price controls are effective in curbing corruption in the market; however, they lead to either surpluses or shortages (Heritage Foundation, 2016). Long periods characterized by low interest rates (expansionary monetary policy) could induce banks to engage in risky activities through increasing collateral value or yield searching (Borio and Zhu, 2012; Rajan, 2010).

$\mathrm{FF}$ is about the reassurance of a sound financial system through the accessibility of credit, diversity of savings, ease of payment and quality of services extended to individuals. A free banking environment induces competition, thereby leading to efficient intermediation between units with a surplus (individuals, companies and governments) and those with shortage, especially investors and entrepreneurs. Driven by forces of supply and demand, markets offer timely information related to prices, especially for rectifying badly made decisions. Therefore, the entire process relies on the level of transparency within the market as well as the reliability of the extended information. Strict requirements of disclosure and independency of auditing guarantee prudent and effective regulatory system. The essential role of the government is ensuring disclosure, transparency and integrity among banking institutions. Any constraints by a government that goes beyond the assurance of the 
$\mathrm{RBF}$

12,4

342

mentioned points, namely transparency and integrity, will most probably lead to curb contestability, efficiency and increase costs of financing activities. For example, the intervention of the government in determining the pricing of capital within the stock market (Heritage Foundation, 2016). Intuitively, a higher score of FF could lead to a considerable variation in the profits and therefore higher risk appetite.

Investment freedom reflects business opportunities and motivations for economic activities diversity, high levels of productivity and job chances. An inductive environment where equity and transparency prevail, all companies regardless of their size and type are treated equally induces contestability and innovation. By contrast, domestic and international constraints on capital movement cause a decline in productivity, bring about instability in making a decision and resources misallocation. In addition, constraints on cross-border-based business activities lead to dwindle in growth opportunities. Having freedom for where and how to invest makes capital flow, allocation and use efficient results in greater returns. In essence, investment restrictions imposed by governments result in a decent level of entrepreneurial activity (Heritage Foundation, 2016). Higher Investment freedom score implies easy access to the market, and hence cost efficiency. However, in contrast, it could induce banks to engage in excessive risk.

Tax burden: the government imposes direct taxes (income tax rates) and indirect taxes (payroll, sales and excise taxes, as well as tariffs and the value-added tax). Tax burden is considered as an impediment to the economic freedom of individuals and companies. It is measured as the relative percentage of all forms of taxes to GDP (Heritage Foundation, 2016). In other words, tax burden reflects the fiscal burden on business activities. A higher score of tax burden implies a hurdle encountering the ability of corporates and individuals to conduct business and achieve their goals in the market, therefore lowering their scope of activities.

Government integrity is one of the fundamental components that reflect the rule of law within a country. The higher the score of this subcomponent of economic freedom index, the more suitable and supporting the environment is within the country to conduct business and related activities. In other words, government integrity reflects how corrupt the market is within that government. People or groups of special interest could gain huge profits at the price of other propel, groups and society at large. Corruption, be it political or economic, often steams from the concentration of power in the government. It appears in different shapes, for example, nepotism, patronage, graft, cronyism and theft. Corruption and government intervention in the economy are interrelated. For instance, too much and unnecessary regulations give plenty of room for theft or graft. Moreover, constraints by the government in some areas only could lead to the creation of informal markets (shadow economy) in other areas. For instance, constraints by the governments that lead to higher costs of transactions may motivate theft and illicit market relationships. In general, transparency is the key to boosting efficiency and the establishment of equal treatment (Heritage Foundation, 2016). Massive direct control by the government could be of a destabilizing effect threat to the banking system due to the excessive government intervention, which in turn leads to inefficiencies and explicit corruption (Miles et al., 2006).

Figure 2 shows the trend of economic freedom index subcomponents in Malaysia that are used in this study over the period 2011-2017. It is clear from the figure that the Malaysian economy is characterized with burdensome taxes, free monetary policy that reflects a stable currency as well as reasonable inflation and mostly free business freedom that reflects easiness of starting business activities in the country - in other words getting a license to establish a business. On the other hand, government integrity is the lowest (repressed) among all the subcomponents. This is very crucial as it reflects the rule of law and how corrupt the market is. FF and investment freedom (mostly unfree) are also the lowest after government integrity. These two subcomponents/financial-related subcomponents are also very critical as they have serious implications for business opportunities, productivity, 


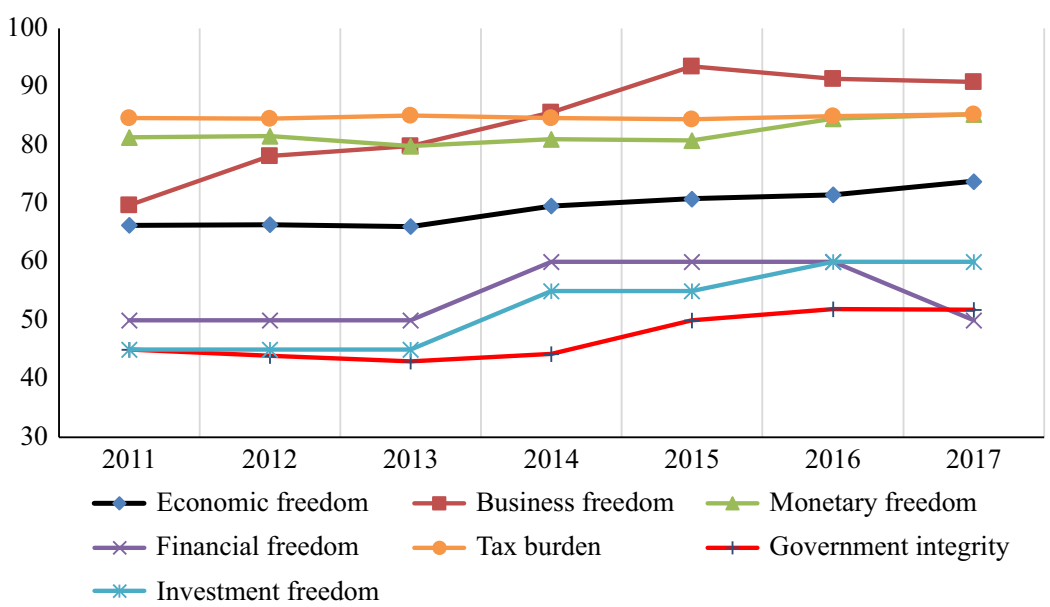

Economic freedom and its subcomponents

capital flows, access to market, accessibility of credit and diversity of savings. Apparently, the Malaysian regulator imposes tight constraints for these subcomponents which may lead to an inadvisable behavior among individuals and corporates, especially banks in terms of their conduct/risk-taking behavior.

\section{Data and variables}

Annual bank-level data of all Malaysian banks over the period 2011-2017 are gathered from various sources, namely FitchConnect database, economic freedom index and its subcomponent are collected from Heritage Foundation, and one macroeconomic variable from the World Bank, namely GDP. The overall number of banks operating in the Malaysian banking sector with available data during the study period is 54, 17 Islamic and 37 conventional, this gives 362 yearly observations.

\subsection{Dependent variable: risk-taking behavior}

Our dependent variable, risk-taking behavior, the $Z$-score is employed which is the most common proxy utilized in literature as a risk-taking behavior indicator, for instance, Hesse and Čihák (2007), Lepetit et al. (2008), Schaeck et al. (2009), Laeven and Levine (2009), and Čihák and Hesse (2010). Following Mokni et al. (2016) we compute Z-score as follows:

$$
Z-\text { score }=\frac{E\left(\mathrm{ROA}_{i t}\right)+\mathrm{CRA}_{i t}}{\mathrm{SD}_{\left(\mathrm{ROA}_{i t}\right)} .}
$$

$E(\mathrm{ROA})$ is the anticipated return on assets, CRA is the ratio of equity capital to total assets and $\mathrm{SD}(\mathrm{ROA})$ is the standard deviation of ROA. Z-score is inversely related to the probability of bank insolvency. A bank becomes insolvent when its asset value drops below its debt. According to Strobel (2010), the insolvency probability can be written as $\mathrm{P}(\mathrm{ROA} \leq-\mathrm{CAR})$. If we use the standardized ROA, the probability would be equal to:

$$
P\left(\frac{\mathrm{ROA}-E(\mathrm{ROA})}{\mathrm{SD}(\mathrm{ROA})} \leq Z \text {-score }\right) .
$$

Therefore, a higher Z-score indicates that the bank is experiencing a more stable status. In order to put outliers and skewness of the distribution in control, the logarithm of the $\mathrm{Z}$-score and its components are computed. 
$\mathrm{RBF}$

344

\subsection{Independent variables}

3.2.1 Economic freedom. Economic freedom, in essence, reflects the freedom extent of individuals and corporates in controlling their business, namely property and labor. In an economically free environment, people are not restricted in terms of production, consumption, investment. Governments in such an environment characterized by faint intervention - in other words, factors of production move freely.

Heritage Foundation's Index of Economic Freedom is used as a proxy for economic freedom, with high index values denoting a free economy and low index values denoting a stringent economy regulation (Sufian and Hassan, 2012). It is scored on a scale of 0-100, where 100 implies the absolute freedom; free 80-100; mostly free 70-79.9; moderately free 60-69.9; mostly unfree 50-59.9; and repressed 0-49.9.

3.2.2 Banking concentration. The commonly employed proxy as a representative of banking sector concentration is the so-called Herfindahl-Hirschman Index (HHI) (Bikker and Haaf, 2002; Abbasoglu et al., 2007; Majid and Sufian 2006; Kadir et al., 2014; Mohammed et al., 2015; Sghaier et al., 2015). HHI is a plain, yet a useful measure for the measurement of concentration in a given industry. It is computed as the sum of the squared market shares of all banks in a certain industry, where market share can be founded on assets, deposits or loans. In our case, concentration is computed based on total assets. The HHI is embodied in the following formula:

$$
\mathrm{HHI}=\sum_{i=1}^{n} S_{i}^{2},
$$

where $S_{i}$ is the bank's market share of the $i$ firm and $n$ represents the number of banks in the sector. The sum of market share is 100 percent $\left(S_{i}^{2}=100 \%\right)$. When HHI index exceeds 0.1000 the market is considered monopolistic, if it is tending toward zero the market is said to be in a state of perfect competition. Hence, the greater the value of $\mathrm{HHI}$ the higher the concentration the market undergoes. If it is below 0.1000 the market is in a state of non-concentration, in case it falls in the range of 0.1000 and 0.1800 the market is experiencing a moderate concentration, and if it exceeds 0.1800 the market is greatly concentrated (Rudkevich et al., 1998).

3.2.3 Bank profitability. Concentrated banking systems are anticipated to increase bank revenues, thereby profits, as a result, this will reduce the fragility of the bank. Hellmann et al. (2000) and Matutes and Vives (2000) are in favor the notion that profit provides a capital buffer to cope with adverse shocks in a financial framework which is not in a stable situation as well as elevate the franchise value of the bank. Consequently, it restrains banks' motives to take on exaggerated risks (Ali et al., 2018; Vives, 2010). ROA is a ratio calculated by dividing the net income over total assets. ROA has been used in most of the studies for the measurement of the profitability of the banks. ROA measures the profit earned per dollar of assets and reflects how well bank management uses the bank's real investment resources to generate profits (Naceur, 2003; Alkassim, 2005; Gropp and Heider, 2007; Jeitschko and Jeung, 2007; Gul et al., 2011). This ratio is defined as follows:

$$
\mathrm{ROA}=\frac{\text { Net income }}{\text { Total assets }}
$$

3.2.4 Capital structure. The link between the degree of risk and capital has been empirically examined by some literature, where two contradictory results were found. The first group detected a positive linkage between the degree of capital and risk. Godlewski (2005) studied the association between capital and bank credit risk using a set of 30 developing countries between 1996 and 2001. This regression was calculated employing the simultaneous 
equation system. It was concluded that there is a positive impact between capital and risk. In addition, Bichsel and Blum (2004) reported a positive association between alterations in capital and risk in a sample of 19 Swiss banks during the period ranging from 1990 to 2002. We make use of most relevant literature in bringing into play a bank's capitalization as gauged via the ratio of equity to total assets (Haque and Shahid, 2016; Selma Mokni et al., 2016). Accordingly, book value of equity/total assets is used as a proxy for bank capital structure, the formula is as follows:

$$
\text { Capital structure }=\frac{\text { Equity }}{\text { Total assets }} \text {. }
$$

\section{Methodology}

In order to address the impact of economic freedom and banking concentration on bank risk-taking behavior, the current research follows a panel data regression model to determine the association between the dependent and independent variables at the industry, Islamic and conventional levels. The panel nature of the present study data permits the usage of panel data methodology. The method was used by several studiesin different areas (Amidu and Abor, 2006; Asimakopoulos et al., 2009; Juan García-Teruel and Martinez-Solano, 2007; Ahmed Haji and Mohd Ghazali, 2013; MarhaYaacob and Che-Ahmad, 2012). Panel data is a methodology that comprises the pooling of observations on units cross-section over various time phases and provides findings that are, basically, not evident in pure time-series or pure cross-section studies (Amidu and Abor, 2006). Asimakopoulos et al. (2009) indicated that their method is different in terms of its equation formula form, regular cross-section, or time-series, where each variable is attached by double subscripts. The form of panel data regression is represented as follows:

$$
Y_{i, t}=\alpha_{i}+\beta X_{i, t}+{ }^{\prime} i, t,
$$

where the subscript $i$ signifies the cross-sectional element and $t$ denotes the time-series element. In this equation, $Y_{i, t}$ represents the model's dependent variable; $X_{i, t}$ contains the set of explanatory variables in the estimation model; and $\alpha i$ is taken to be constant over time $t$ and definite to the individual cross-sectional unit $i$.

Models estimation from the panel data method requires that the study should first specify whether $t$ a correlation exists among the unobservable heterogeneity $n i$ of each firm and the model's explanatory variables (Juan García-Teruel and Martinez-Solano, 2007). If a correlation exists (fixed effects), it would be possible to get a consistent estimation using the within-group estimator. On the other hand, random effects is a more effective estimator which can be derived by estimating the equation by generalized least squares. The regular method to identify whether the effects are fixed or random is to run the Hausman test under the null hypothesis (correlation does not exist between the unobservable heterogeneity and the model's explanatory variables). If the null hypothesis is accepted, there would be random effect; otherwise, the effects are regarded to be fixed. Through this way, the analysis can achieve a more effective estimator of $\beta$ (Juan García-Teruel and Martinez-Solano, 2007).

Selection of this methodology in the current study is due to its powerful mechanisms and advantages that provide outputs that cannot be predictable and expected through individual studies of either times-series or cross-section data (Amidu and Abor, 2006; Asimakopoulos et al., 2009; Juan García-Teruel and Martinez-Solano, 2007). In other words, the benefits of panel data technique are rooted in the concept of this method which assumes that corporations, individuals or countries are heterogeneous which is a fact that is not supposed and assumed in cross-section and time-series data literature which make them more exposed to the risk of getting unbiased results. This method delivers more variability, 
$\mathrm{RBF}$ 12,4

more informative data, more degrees of freedom and efficiency and less collinearity. Furthermore, the panel data method has better statistical techniques than other methods as it allows for more data points and it includes the investigation of a specific substance within several spots periodically over a defined time setting (Kyereboah-Coleman, 2007; MarhaYaacob and Che-Ahmad, 2012). Following Ghosh (2016), the first model for this study is structured as shown in the following equation:

$$
\begin{aligned}
& \ln \left(Z_{\text {score }_{i t}}\right)=\alpha+\beta_{1} \ln \left(\text { Econfree }_{i t}\right)+\beta_{2} \ln \left(\mathrm{HHI} \text { asset }_{i t}\right)+\beta_{3} \ln \left(\mathrm{ROA}_{+} 1_{i t}\right) \\
& +\beta_{4} \ln \left(E Q / T A_{i t}\right)+\gamma_{1} \ln \left(\text { Net loans } / T A_{i t}\right)+\gamma_{2} \ln \left(\text { GDPgrowth } / T A_{i t}\right) \\
& +\gamma_{3} \ln \left(\text { Asset }_{i t}\right)+\gamma_{4} \text { Dummy own }+\varepsilon_{i t} \text {, }
\end{aligned}
$$

where $Z$-score, independent variable, used as a proxy for risk-taking behavior, Econfree: economic freedom, HHI asset: concentration in the market based on total assets, ROA +1: proxy for profitability, we add 1 to avoid the elimination of negative values as we subject variables to Ln function, EQ/TA: capital structure, Net loan/total asset: proxy for intermediation, GDP growth rate: macroeconomic variable, Assets: to control for size, Dummy own: A dummy variable for ownership that takes the value of one (1) if the bank is foreign; and Zero (0) if the bank is local.

Following Molyneux et al. (2010) and Sarkar and Sensarma (2016), bank size (total assets), the ratio of net loans/total assets, profitability (return on assets/ROA), capital structure (total equity/total assets) and GDP growth rate are considered control variables.

In order to address the impact of economic freedom index subcomponents on risk-taking, we selected six relevant subcomponents, namely business freedom, monetary freedom, FF, investment freedom, tax burden and government integrity. The selection of these six subcomponents is due to their relevance to the financial aspect. To this end, we develop the following equation where $b$ represents the bank, $t$ represents the time-series element and $f$ the subcomponents of economic freedom index:

$$
\ln \left(Z_{\text {score }_{f b t}}\right)=\alpha_{b t}+\beta_{f} \ln \text { Freedom }_{f b t}+\beta_{1} \ln \left(\text { HHI } \text { asset }_{b t}\right)+\gamma_{1} X_{b t}+\gamma_{2} \text { DumOwn }+\varepsilon_{b t},
$$

where Z-score represents risk-taking behavior of bank $b$ in light of subcomponent $f$ at time $t, \alpha$ the bank-specific effect, Freedom the subcomponent of economic freedom, HHIassetconcentration in the market based on total assets, $X$ represents bank-specific and macroeconomic controls (return on assets/ROA, size, capital structure (total equity/total assets), net loans/total assets, GDP growth rate), $\varepsilon$ : is the error term, and DumOwn represents dummy ownership variable; it takes one (1) if the bank is foreign; and Zero (0) if the bank is local.

The coefficient of interest in Equation (2) is $\beta_{f}$ which represents the impact exerted by the economic index subcomponent $f$. Therefore, the reported results for Equation (2) will be limited to coefficient $\beta_{f}$ in order to confirm that the total impact of the subcomponents is corresponding with that of the entire index (coefficient $\beta_{1}$ in Equation (1)), in addition to figuring out which subcomponent is more significant in determining bank risk-taking behavior.

\section{Findings, analysis and discussion}

\subsection{Summary statistics}

Table II reports the main descriptive statistics of the variable used in the first model. The Z-score of banks is distributed with a mean value of 55.47 and standard deviation of 47.023. The very high standard deviation signifies a very significant variation in the level of risk-taking across banks. This also implies immense heterogeneity in the relative risk condition of banks across the market. 
Base on Table III and Figure 3, and with respect to concentration in the asset market, as stipulated in the US Merger Guidelines [6] that Herfindahl indices less than 0.1000 indicates that the market is not concentrated, between 0.1000 and 0.1800 moderatelyconcentrated and indices above 0.1800 points out that the concentration prevails in the market (Sufian and Shah Habibullah, 2013). Therefore, the mean values for HHI calculated based on total assets show that the market for all banks experiences a non-concentration condition, whereas for conventional and Islamic banks the market is moderately concentrated. Concentration for all banks as well as conventional decreased in the first year, from 2011 to 2012 indicating a reduction in the market power, and then it remained almost stable with slight increases for the rest of the period. On the other hand, for Islamic banks, the market is moderately concentrated. However, it is slightly more concentrated than conventional banks. It fell sharply in the first year; this is an indication of the immense reduction in market power in the Islamic banking sector. Then it showed a slight increase for the second year, from 2012 to 2013, after that it experienced a stable trend from 2013 to 2015, and for the remaining two years of the study period, it indicates a moderate increase but it remained within the area of moderate concentration. Concentration in the Islamic asset market is higher than that of all

\begin{tabular}{lccccc}
\hline Variable & Mean & SD & Min. & Max. & No. of Obs. \\
\hline$Z$-score & 55.472 & 47.023 & 0.9098 & 253.3925 & 362 \\
HHIA & 0.0989 & 0.0087 & 0.0916 & 0.123 & 362 \\
ROA & 0.00759 & 0.03434 & -0.5618 & 0.1660 & 362 \\
EcoFree & 69.32238 & 2.79438 & 66.1 & 73.8 & 362 \\
EQ/TA & 0.1550 & 0.1427 & 0.04324 & 0.9946 & 362 \\
NetloanTA & 0.4630718 & 0.2545469 & 0 & 1.256963 & 362 \\
GDPgrowth & 5.226685 & 0.6062522 & 4.22 & 6.007 & 362 \\
Asset & $53,059.72$ & $109,747.4$ & 22.22 & $765,301.8$ & 362
\end{tabular}

freedom and its subcomponents

347

Table II. Summary statistics of variables used in the models (2011-2017)

\begin{tabular}{|c|c|c|c|c|c|c|c|c|}
\hline & 2011 & 2012 & 2013 & 2014 & 2015 & 2016 & 2017 & Table III. \\
\hline Whole sample & 0.123 & 0.0916 & 0.0930 & 0.0972 & 0.0984 & 0.0983 & 0.0980 & Herschman \\
\hline Islamic & 0.160 & 0.119 & 0.135 & 0.135 & 0.137 & 0.148 & 0.152 & Index (HHI) based on \\
\hline Conventional & 0.164 & 0.125 & 0.128 & 0.134 & 0.137 & 0.139 & 0.140 & total assets \\
\hline
\end{tabular}

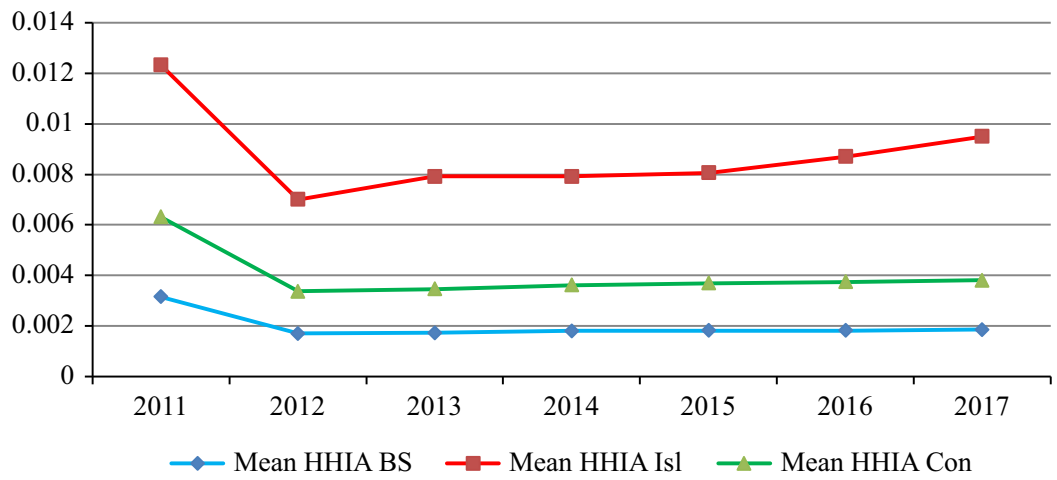

Figure 3. Plot graph of mean values of HHI asset for banking sector, Islamic and conventional banks 


\section{$\mathrm{RBF}$ 12,4}

\section{8}

Figure 4.

Plot graph of mean values of $Z$-score for the banking sector, Islamic and conventional banks banks and conventional banks due to the reasoning that there is a less considerable number of Islamic banks that possess the great portion assets of the Islamic industry; in other words, assets are distributed mainly among a limited number of banks. This is due to the fact that those few banks are very competitive as compared to their rivals. On the contrary, the mean values for both all banks and conventional bank concentrations in the assets market are lower indicating that assets are distributed among many banks, reduction in market power, and all banks are healthy competitors.

From a theory perspective, when the size distribution of banks indicates inequality, it is a mark that concentration is very immense. However, in Malaysia conventional and all banking sector concentration seems to be low as shown in Figure 3. This low concentration is a reflection of the competitiveness in the asset market. In contrast, the Islamic banking sector shows a relatively higher degree of concentration, which indicates a lesser competition as compared to the whole and conventional banking sectors.

\subsection{Trend of Z-score mean values}

Figure 4 illustrates the behavior of Z-score values for the sector at large (BS), Islamic (Isl) and conventional (Con) banks during the study period (2011-2017). It is very apparent from the figure that the mean values of $Z$-score for the banking sector at large and conventional banks surpass those of Islamic banks. Therefore, and according to the interpretation of Z-score, the higher the better, Islamic banks are more prone to insolvency compared to conventional ones. Z-score mean values behavior of conventional banks surpass those of the banking sector and both moves in a parallel direction; this implies that the dominance of conventional banks over the banking sector is very clear because as Islamic banks Z-score values are added to conventional values the trend still follows in the same pattern as that of conventional banks Z-score.

\subsection{Regression results}

Table IV reports the results of the first model for all categories of banks. We report a random effect model results based on Breusch-Pagan LM and Huasman tests. Economic freedom exerts a negative impact on risk-taking for both Islamic and conventional banks; however, it is more severe for Islamic banks. When the economy is free, it is open for new contestants, this in turn fuels competition. The results show that concentration influences risk-taking negatively - that means causing a decline in Z-score (getting closer to default). For Islamic banks, the influence is greater than the one placed on conventional banks. This may attribute to the fact that Islamic banks get engaged in riskier activities because of its complicate models of business, or due to the lack of many financial instruments being subject to shariah principles (Islamic law). ROA and EQ/TA both indicates a positive

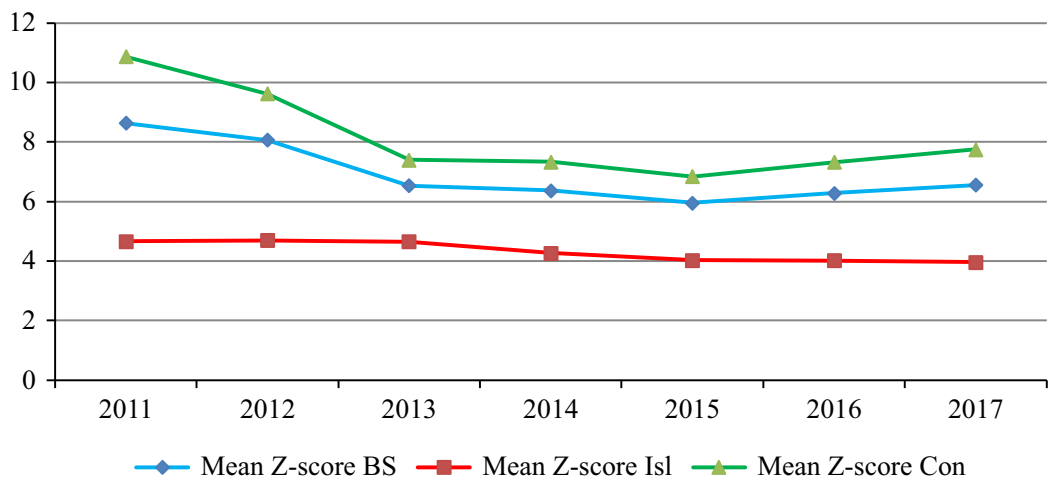




\begin{tabular}{|c|c|c|c|c|}
\hline & $\begin{array}{l}\text { All banks } \\
\text { random affect }\end{array}$ & $\begin{array}{l}\text { Islamic banks } \\
\text { random effect }\end{array}$ & $\begin{array}{l}\text { Conventional banks } \\
\text { random effect }\end{array}$ & $\begin{array}{l}\text { Economic } \\
\text { freedom and its }\end{array}$ \\
\hline Constant & $14.61(5.56) * * *$ & $17.32(2.45) * *$ & $14.80(5.73) * * * *$ & \\
\hline LnEconfree & $-2.95(-5.08)^{* * * *}$ & $-4.02(-2.21)^{* * *}$ & $-2.78(-4.34) * * *$ & \\
\hline LnHHIasset & $-0.12(-0.34)$ & $-0.52(-0.64)$ & $0.22(1.16)$ & \\
\hline LnROA+1 & $3.42(9.25)^{* * * *}$ & $13.54(2.13)^{* * *}$ & $3.24(10.56)^{* * * *}$ & \\
\hline LnEqasset & $0.99(6.45) * * *$ & $1.76(2.05)^{* * *}$ & $0.88(8.9)^{* * * *}$ & 34 \\
\hline LnnetloawnTA & $0.046(1.73)$ & $-0.18(-0.60)$ & $0.056(1.88)^{*}$ & \\
\hline LnGDPgrowth & $0.28(2.79)^{* * * *}$ & $0.008(0.03)$ & $0.37(3.34)^{* * * *}$ & \\
\hline Logasset & $0.16(0.77)$ & $0.93(0.90)$ & $0.017(0.15)$ & \\
\hline Dumown & $0.25(1.28)$ & $-0.12(-0.22)$ & $0.47(2.08)$ & \\
\hline Breusch-Pagan LM test & $658.31(0.0000)$ & $154.94(0.0000)$ & $532.46(0.0000)$ & \\
\hline Hausman test & $2.25(0.9446)$ & 2.78 (0.9049) & $1.28(0.9890)$ & \\
\hline Observations & 362 & 144 & 248 & Table I \\
\hline Multicollinearity (vif) & 1.49 & 2.19 & 1.74 & of panel \\
\hline Hetero ( $\chi^{2}$-stat) & Vce cluster (robustness) & Vce cluster (robustness) & Vce cluster (robustness) & e \\
\hline Wald test & $377.00(0.0000)$ & $12.77(0.1202)$ & $385.69(0.0000)$ & $\begin{array}{l}\text { anking sector, } \\
\text { Islamic and }\end{array}$ \\
\hline$R^{2}$ (within) & 0.38 & 0.23 & 0.62 & \\
\hline$F$-statistics & $32.84(0.0000)$ & $2.08(0.044)$ & $385.69(0.0000)$ & dependent variab \\
\hline \multicolumn{4}{|c|}{ Notes: *******Significance at 10,5 and 1 percent levels, respectively } & " \\
\hline
\end{tabular}

significant impact for the whole sector, conventional and Islamic banks. However, in terms of magnitude, the impact is remarkably higher than shown for all banks and conventional banks; this is not surprising as most of the Islamic contracts are equity based. The ownership dummy variable is insignificant; this signifies that there are no differences between foreign and domestic Islamic banks when it comes to risk-taking.

A higher level of economic freedom means a more flexible economy in terms of entry of new rivals into the banking arena, thereby fueling competition. Economic freedom for Malaysian is ranked the 12th in the world with a level of 74.5 out of 100 in the year 2018 suggesting the considerable economic freedom, and it is ranked 6th among 43 countries in the Asia-Pacific region, and its overall score is above the regional and world averages (Heritage Foundation, 2016). On the other hand, Malaysian FF ranged between 50 and 60 during the study period; this implies that the Malaysian central banks have a burdensome task supervising and regulating the financial sector, with the insufficient capability to prevent fraud and enforcement of contracts. The government practices very active control over banks with a considerable ownership share of the whole sector. During the sample period, the economic freedom index exhibited an increasing trend from 66.3 to 73.8. This increasing trend implies that the sign of economic freedom impact in the regression results matches the set hypothesis that economic freedom exerts a negative impact on Z-score (distance to default) - in other words, it fosters bank appetite toward risk, so they can survive in the market, these results are supported by Ghosh (2016). The impact varies according to the type of bank. For conventional banks, the impact seems to be lower than that of Islamic ones; this is due to the fact that conventional banks are better rivals compared to Islamic ones. This is not surprising as Islamic banking is still in its infancy stage (this notion is still controversial). In addition, the instruments being used by Islamic banks are still limited due to compliance with shariah principle and prohibition of interest in comparison with an abundance of instruments available for conventional banks. Furthermore, Islamic banks have many exposures in addition to those conventional banks are exposed to. Business activities of Islamic banks are more complex and consider due diligence owing to being bound by shariah principles (mainly they are built on the basis of risk-sharing; however, in practice, this is still controversial in terms of whether they practically share or transfer risk). 


\section{$\mathrm{RBF}$ 12,4}

\section{0}

Table V.

Summary statistics of economic freedom index components

\subsection{Impact of economic freedom subcomponents on risk-taking behavior}

Table $\mathrm{V}$ reports the summary statistics of economic freedom index components. It is clear from the table that business freedom and investment freedom are of a high variation. This may be an implication for difficulties in projections and fluctuations of the Malaysia economic environment. In contrast, tax burden shows the lowest standard deviation (0.32) and the highest mean (84.79) on a scale of 100, which maybe an indication of how burdensome taxes in Malaysia are.

Table VI reports the regression results of the impact of economic freedom index subcomponents on risk-taking behavior (Z-score). Based on the standard errors clustered at the bank level, and based on both Breusch-Pagan LM and Hausman tests, random effects seem superior over fixed effects due to the non-correlation between regressors and timeinvariant bank-specific variables.

Remarkably, all components exert a significant negative impact on the banking sector at large, Islamic and conventional banks, except for tax burden which turns to be insignificant for the whole banking sector and Islamic banks. The estimated result for the subcomponents corresponds with the estimated result of the entire index, economic freedom index.

For conventional banks, all subcomponents exert a significant negative impact on risktaking at a 1 percent significance level. On the other hand, for Islamic banks, all subcomponents exert a significant negative impact on risk-taking at a 5 percent level of significance, except for monetary freedom and tax burden, which turn to be insignificant, yet they are influencing risktaking negatively.

Governments with excessive intervention with the market forces lead to less flexibility with regard to decision making, in addition to suppression of innovative activities for banks in terms of novel services and products. Consequently, banks are induced to engage in risky activities in the asset portfolio in order to compensate for diminishing profit margins.

\begin{tabular}{lcccc}
\hline Variable & Mean & SD & Min. & Max. \\
\hline Economic freedom index & 69.32 & 2.79 & 66.1 & 73.8 \\
Business freedom & 48.72 & 7.63 & 69.7 & 93.5 \\
Monetary freedom & 82.06 & 1.92 & 79.8 & 85.3 \\
Financial freedom & 54.47 & 4.98 & 50 & 60 \\
Investment freedom & 52.41 & 6.44 & 45 & 60 \\
Government integrity & 47.23 & 3.70 & 43 & 52 \\
Tax burden & 84.79 & 0.32 & 84.4 & 85.3 \\
\hline
\end{tabular}

Table VI.

Results of panel data analysis for economic freedom and its subcomponents for the banking sector, Islamic and conventional banks dependent variable: $Z$-score

\begin{tabular}{lccc}
\hline & $\begin{array}{c}\text { All banks } \\
\text { Random affect }\end{array}$ & $\begin{array}{c}\text { Islamic banks } \\
\text { Random effect }\end{array}$ & $\begin{array}{c}\text { Conventional banks } \\
\text { Random effect }\end{array}$ \\
\hline $\begin{array}{l}\text { Economic freedom } R^{2} \mathrm{EF} \\
\text { Subcomponents }\end{array}$ & $-2.95(-5.08)^{* * * *} 0.38$ & $-4.02(-2.21)^{* * *} 0.23$ & $-2.78(-4.34)^{* * * *} 0.62$ \\
Business freedom $R^{2}$ & $-1.39(-5.17)^{* * *} 0.37$ & $-1.82(-2.58)^{* *} 0.23$ & $-1.30(-4.68)^{* * *} 0.62$ \\
Monetary freedom $R^{2}$ & $-2.76(-3.72)^{* * *} 0.35$ & $-2.81(-1.25) 0.18$ & $-2.60(-3.14)^{* * *} 0.57$ \\
Financial freedom $\mathrm{R}^{2}$ & $-0.74(-4.07)^{* * *} 0.34$ & $-0.84(-2.00)^{* *} 0.19$ & $-0.62(-3.70)^{* * *} 0.57$ \\
Investment freedom $R^{2}$ & $-0.95(-5.21)^{* * *} 0.38$ & $-1.25(-2.24)^{* *} 0.23$ & $-0.90(-4.55)^{* * *} 0.62$ \\
Government integrity $R^{2}$ & $-1.36(-4.88)^{* * *} 0.37$ & $-1.75(-2.24)^{* *} 0.22$ & $-1.25(-3.94)^{* * *} 0.60$ \\
Tax burden $R^{2}$ & $-4.46(-1.51) 0.32$ & $-0.52(-0.06) 0.17$ & $-6.09(-2.02)^{* *} 0.55$ \\
No. of observations & 362 & 144 & 248
\end{tabular}

Notes: Economic freedom index and its components are subject to LN. All regressions include all bank-level and macroeconomic controls; however, these are not reported. *******Significance level at 10, 5 and 1 percent levels, respectively 
A low government integrity score reflects how deep the government engages in redundant regulation as well as a sign of a dysfunctional market in terms of information and shadow economy, and maybe special interest groups.

In Figure 2, two subcomponents of economic freedom index show openness, namely business freedom, monetary freedom, in addition to a high tax burden. On the other hand, the other three subcomponents, namely investment freedom, FF, in addition to the low integrity of the government show very restricted conditions and deep interference with the market forces. Despite the fact that business freedom is high, it exerts a negative impact on the risk-taking of banks regardless of their type. This may signify that huge business freedom lends more room for banks to engage in risky activities. However, this also may attribute to the restricted financial and investment freedom as they are very low, in addition to the high tax burden. High risk-taking could be fueled with increasing level of business freedom as it leads to variability in profits, and therefore higher risk-taking in the hope to compensate for decreasing profit margins. Monetary freedom turns to be insignificant except for conventional banks, this may attribute to the fact that conventional banks are very sensitive to interest rate variation being a fundamental component of monetary policy and the core income of conventional banks. Conventional banks extend loans and charge interest on it. Monetary freedom in Malaysia based on Figure 2 is considerably high, and hence allowing plenty of room for banks to give out more loans, especially conventional ones, which in turn prompt their risk-taking, or perhaps conventional banks extend excessive loans in order to maintain their market share or increase it.

All subcomponents' effects on Islamic banks surpass those on conventional banks, except for taxes burden, which is insignificant for Islamic banks, but significant and severe for conventional banks.

To sum up, the economic freedom index and its relevant components exert a similar impact on both Islamic and conventional banks. The effect is slightly higher for Islamic banks as compared to conventional ones. Nevertheless, the behavior of conventional and Islamic banks is identical in light of the impact of economic freedom and its relevant subcomponents on risk-taking of banks. It is not surprising due to a number of reasons. First, conventional banks dominate the banking landscape in Malaysia; they are also better off in terms of the availability and variety of financial instruments used when engaging in contracts as opposed to Islamic banks that have to only deal with instruments that comply with Shariah principle (Islamic law). Second, the Islamic business model is complex being restricted to work under shariah principles. Third, both types of banks are operating in the same environment where dominance is for conventional banks. In the context of Malaysia, the results suggest a fundamental role of policy makers and regulators. While an open economy can boost performance, it can also fuel banks' inclination towards engaging in risky activities. Hence, government intervention should be reasonable where it does not jeopardize nor allowing vast room for banks to engage in risky activities so that it can maintain banking system soundness.

\section{Conclusion and policy implications}

By using data of all banks in the dual banking system of Malaysia covering the period 2011-2017, the present study investigates economic freedom impact on the banking sector at large and make a comparison between risk-taking behavior (Z-score) of Islamic and conventional banks in light of the impact exerted by the former on the latter. The findings reveal that economic freedom and its six relevant subcomponents place a negative influence risk-taking on both Islamic and conventional banks and the banking system at large in Malaysia. However, the magnitude of the exerted impact varies between the two types of banks. Conventional banks appear to be slightly less influenced compared to Islamic banks. This suggests that government intervention is crucial in setting the economic freedom level 
$\mathrm{RBF}$

12,4

352

that better serves the soundness of banks by curbing their risk-taking excessiveness. For conventional banks, tax burden, monetary freedom, business freedom and government integrity, respectively, are very significant and crucial in determining risk-taking. In contrast, for Islamic banks, monetary freedom, business freedom, government dignity, investment freedom, respectively, are the most important subcomponents that determine the risk-taking of banks.

Banking sector concentration exerts a negative but insignificant impact on risk-taking. Both ROA and capital structure exert a positive favorable impact on Z-score for both banks; however, conventional banks are better off in terms of distance to default as compared to Islamic banks. This is not surprising as conventional banks are the dominant of the Malaysian banking sector by virtue of their experience and being in existence prior to Islamic banks, which are still in a position looking for more market share.

The findings of the study have important policy implications. In light of the increased concentration out of acquisition and merger processes that have impinged on the banking sector of Malaysia, regulators, policy makers and banks managements are in search of best practices in order to allocate and use their resources in way that ensures better performance and stability, thereby soundness of the entire banking system. Policy makers and regulators are recommended to look into the level of economic freedom through investigating its subcomponents. This can be fulfilled by investigating and setting best thresholds for economic freedom index subcomponents that better serve stability and lessen banks' inclination towards risk-taking. The findings, implicitly, suggest that government interference with business activities has a considerable influence on banks' risk-taking behavior.

Further research could be conducted in terms of deciding on the best level of economic freedom that ensures less risk-taking inclination by banks of different types but operating in the same regulatory environment in a way that leads to boosting productivity, efficiency and stability. This would not be an easy task as the technique to be used in determining the level of economic freedom has to be chosen with due care due to the sensitivity of the implications.

\section{Notes}

1. Rashid Hussain Bank (RHB) resulted out of a merger that took place between DCB Bank and Kwong Yik Bank as the second-largest bank, and later agreed to buy Sime Bank, which underwent huge losses during the second half of 1997.

2. As of the end of 1997 , ten commercial banks were given the tier-1 status.

\section{References}

Abbasoglu, O.F., Aysan, A.F. and Günes, A. (2007), "Concentration, competition, efficiency and profitability of the Turkish banking sector in the post-crises period", Banks and Bank Systems, Vol. 2 No. 3, p. 106.

Ahmed Haji, A. and Mohd Ghazali, N.A. (2013), "A longitudinal examination of intellectual capital disclosures and corporate governance attributes in Malaysia", Asian Review of Accounting, Vol. 21 No. 1, pp. 27-52.

Akthar Aziz, Z. (2009), "Islamic finance and financial stability", Address delivered at the High Level Conference on Financial Stability, Bank Negara Malaysia, Kuala Lampur, available at: www.bis. org/review/r091130d.pdf (accessed September 8, 2019).

Ali, M.S.B., Intissar, T. and Zeitun, R. (2018), "Banking concentration and financial stability. New evidence from developed and developing countries", Eastern Economic Journal, Vol. 44 No. 1, pp. 117-134.

Alkassim, F.A. (2005), "The profitability of islamic and conventional banking in the GCC countries: a comparative study", Journal of Review of Islamic Economics, Vol. 13 No. 1, pp. 5-30. 
Amidu, M. and Abor, J. (2006), "Determinants of dividend payout ratios in Ghana", The Journal of Risk Finance, Vol. 7 No. 2, pp. 136-145.

Asimakopoulos, I., Samitas, A. and Papadogonas, T. (2009), "Firm-specific and economy wide determinants of firm profitability: Greek evidence using panel data", Managerial Finance, Vol. 35 No. 11, pp. 930-939.

Baier, S.L., Clance, M. and Dwyer, G.P. (2012), "Banking crises and economic freedom. 2012 economic freedom dataset", Published in Economic Freedom of the World, 2012 Annual Report, 201.

Bank Negara Malaysia (1999), “Bank Negara Malaysia annual report, 1999”, Bank Negara Malaysia, Kuala Lumpur.

Bank Negara Malaysia (2016), "Bank Negara Malaysia annual report, 2016”, Bank Negara Malaysia, Kuala Lumpur.

Berger, A.N., Hasan, I. and Zhou, M. (2009), "Bank ownership and efficiency in China: what will happen in the world's largest nation?”, Journal of Banking \& Finance, Vol. 33 No. 1, pp. 113-130.

Bichsel, R. and Blum, J. (2004), "The relationship between risk and capital in Swiss commercial banks: a panel study", Applied Financial Economics, Vol. 14 No. 8, pp. 591-597.

Beck, T., Demirgüç-Kunt, A. and Levine, R. (2006), "Bank concentration, competition, and crises: first results", Journal of Banking \& Finance, Vol. 30 No. 5, pp. 1581-1603.

Bikker, J.A. and Haaf, K. (2002), "Measures of competition and concentration in the banking industry: a review of the literature", Economic \& Financial Modelling, Vol. 9 No. 2, pp. 53-98.

Borio, C. and Zhu, H. (2012), "Capital regulation, risk-taking and monetary policy: a missing link in the transmission mechanism?”, Journal of Financial Stability, Vol. 8 No. 4, pp. 236-251.

Carey, M. and Stulz, R.M. (2005), The Risks of Financial Institutions, National Bureau of Economic Research, available at: www.nber.org/papers/w11442 (accessed June 30, 2019).

Čihák, M. and Hesse, H. (2010), "Islamic banks and financial stability: an empirical analysis", Journal of Financial Services Research, Vol. 38 Nos 2-3, pp. 95-113.

De Haan, J. and Sturm, J.E. (2003), "Does more democracy lead to greater economic freedom? New evidence for developing countries", European Journal of Political Economy, Vol. 19 No. 3, pp. 547-563.

Fah, C.T. and Ariff, M. (2017), “Competition in the Malaysia's banking industry, Quo Vadis”, International Journal of Economics \& Management, Vol. 11 No. 3, pp. 897-920.

Gajurel, D.P. and Pradhan, R.S. (2012), "Concentration and competition in Nepalese banking”, Journal of Business, Economics, Vol. 1 No. 1, pp. 5-16.

Godlewski, C.J. (2005), "Bank capital and credit risk taking in emerging market economies", Journal of Banking Regulation, Vol. 6 No. 2, pp. 128-145.

Ghosh, S. (2016), "Does economic freedom matter for risk-taking? Evidence from MENA banks", Review of Behavioral Finance, Vol. 8 No. 2, pp. 114-136.

Gropp, R. and Heider, F. (2007), "What can corporate finance say about banks' capital structures”, European Central Bank working paper.

Gul, S., Irshad, F. and Zaman, K. (2011), "Factors affecting bank profitability in Pakistan", Romanian Economic Journal, Vol. 14 No. 39, pp. 61-87.

Hakim, A. and Chkir, A. (2014), "Market structure and concentration in islamic and conventional banking", International Journal of Financial Services Management, Vol. 7 Nos 3-4, pp. 246-267.

Haque, F. and Shahid, R. (2016), "Ownership, risk-taking and performance of banks in emerging economies: evidence from India”, Journal of Financial Economic Policy, Vol. 8 No. 3, pp. 282-297.

Hellmann, T.F., Murdock, K.C. and Stiglitz, J.E. (2000), "Liberalization, moral hazard in banking, and prudential regulation: are capital requirements enough?”, American Economic Review, Vol. 90 No. 1, pp. 147-165. 
$\mathrm{RBF}$

12,4

Heritage Foundation (2016), 2016 Index of Economic Freedom, The Heritage Foundation, Washington, DC, available at: www.heritage.org/ index (accessed September 30, 2019).

Hesse, H. and Čihák, M. (2007), "Cooperative banks and financial stability”, IMF Working Paper No. 07/02, IMF, Washington, DC.

Honohan, P. (2000), "Banking system failures in developing and transition countries: diagnosis and prediction”, Economic Notes, Vol. 29 No. 1, pp. 83-109.

Ibrahim, M.H., Salim, K., Abojeib, M. and Yeap, L.W. (2019), "Structural changes, competition and bank stability in Malaysia's dual banking system”, Economic Systems, Vol. 43 No. 1, pp. 111-129.

Iqbal, Z. and Mirakhor, A. (2007), An Introduction to Finance: Theory and Practice, John Wiley \& Son (Asia) Pvt. Ltd.

Jeitschko, T.D. and Jeung, S.D. (2007), "Do well-capitalised banks take more risk? Evidence from the Korean banking system”, Journal of Banking Regulation, Vol. 8 No. 4, pp. 291-315.

Juan García-Teruel, P. and Martinez-Solano, P. (2007), "Effects of working capital management on SME profitability", International Journal of Managerial Finance, Vol. 3 No. 2, pp. 164-177.

Kadir, H.A., Habibullah, M.S., Law, S.H. and Mohamed, A. (2014), "Market structure and bankcompetition conditions in Malaysia", Journal of Technology Management and Business, Vol. 1 No. 2, pp. 1-34.

Kim, D. and Santomero, A.M. (1988), "Risk in banking and capital regulation", The Journal of Finance, Vol. 43 No. 5, pp. 1219-1233.

Knight, F.H. (1921), Risk, Uncertainty and Profit, Dover 2006 unabridged republication of the edition published by, Houghton Mifflin Company, Boston, MA and New York, NY.

Kyereboah-Coleman, A. (2007), "The impact of capital structure on the performance of microfinance institutions", The Journal of Risk Finance, Vol. 8 No. 1, pp. 56-71.

Laeven, L. and Levine, R. (2009), "Bank governance, regulation and risk taking”, Journal of Financial Economics, Vol. 93 No. 2, pp. 259-275.

Lepetit, L., Nys, E., Rous, P. and Tarazi, A. (2008), "Bank income structure and risk: an empirical analysis of European banks", Journal of Banking \& Finance, Vol. 32 No. 8, pp. 1452-1467.

Majid, A.M.Z. and Sufian, F. (2006), "Consolidation and competition in emerging market: an empirical test for Malaysian banking industry", Economic Change and Restructuring, Vol. 39, pp. 105-124.

Majid, M.Z.A. and Sufian, F. (2007), "Market structure and competition in emerging market: evidence from Malaysian Islamic Banking Industry", Journal of Economic Cooperation, Vol. 28 No. 2, pp. 99-121.

MarhaYaacob, N. and Che-Ahmad, A. (2012), "Adoption of FRS 138 and audit delay in Malaysia”, International Journal of Economics and Finance, Vol. 4 No. 1, pp. 167-176.

Matutes, C. and Vives, X. (2000), "Imperfect competition, risk taking, and regulation in banking", European Economic Review, Vol. 44 No. 1, pp. 1-34.

Miles, M., Holmes, K.R. and O'Grady, M.A. (2006), 2006 Index of Economic Freedom, The Heritage Foundation and The Wall Street Journal, Washington, DC.

Mohammed, N., Ismail, A.G. and Muhammad, J. (2015), "Evidence on market concentration in Malaysian dual banking system”, Procedia-Social and Behavioral Sciences, Vol. 172, pp. 169-176.

Mokni, R.B.S., Rajhi, M.T. and Rachdi, H. (2016), "Bank risk-taking in the MENA region: a comparison between islamic banks and conventional banks", International Journal of Social Economics, Vol. 43 No. 12, pp. 1367-1385.

Molyneux, P., Liu, H. and Wilson, J. (2010), "Measuring competition and stability: recent evidence for European Banking (No. 10020)", Bangor Business School, Prifysgol Bangor University, Cymru.

Naceur, S.B. (2003), “The determinants of the Tunisian banking industry profitability: panel evidence", paper presented at the 10th annual Economic Research Forum (ERF) Conference, Morocco, available at: www.mafhoum.com/press6/174E11.pdf (accessed June 24, 2019). 
Rajan, R. (2010), "Why we should exit ultra-low rates: a guest post", The New York Times, Freakonomics, August, p. 25.

Rudkevich, A., Duckworth, M. and Rosen, R. (1998), "Modeling electricity pricing in aderegulated generation industry: the potential for oligopoly pricing in a poolco", The Energy Journal, Vol. 19 No. 3, pp. 19-48.

Saiti, B., Bacha, O.I. and Masih, M. (2016), "Testing the conventional and islamic financial market contagion: evidence from wavelet analysis”, Emerging Markets Finance and Trade, Vol. 52 No. 8, pp. 1832-1849.

Sarkar, S. and Sensarma, R. (2016), “The relationship between competition and risk-taking behaviour of Indian banks", Journal of Financial Economic Policy, Vol. 8 No. 1, pp. 95-119.

Schaeck, K., Cihak, M. and Wolfe, S. (2009), “Are competitive banking systems more stable?”, Journal of Money, Credit and Banking, Vol. 41 No. 4, pp. 711-734.

Schonberg, T., Fox, C.R. and Poldrack, R.A. (2011), "Mind the gap: bridging economic and naturalistic risk-taking with cognitive neuroscience", Trends in Cognitive Sciences, Vol. 15 No. 1, pp. 11-19.

Selma Mokni, R.B., Rajhi, M.T. and Rachdi, H. (2016), "Bank risk-taking in the MENA region: a comparison between islamic banks and conventional banks", International Journal of Social Economics, Vol. 43 No. 12, pp. 1367-1385.

Sghaier, M.L., Philippe, G. and Mansouri Faysal, A. (2015), "Estimation of the islamic banks competitive structure vs conventional banks one", Global Journal of Management and Business Research, Vol. 15 No. 7, pp. 19-29.

Sharma, M.K. and Bal, H.K. (2010), "Bank market concentration: a case study of India", International Review of Business Research Papers, Vol. 6 No. 6, pp. 95-107.

Soedarmono, W., Machrouh, F. and Tarazi, A. (2013), "Bank competition, crisis and risk taking: evidence from emerging markets in Asia", Journal of International Financial Markets, Institutions and Money, Vol. 23, pp. 196-221.

Strobel, F. (2010), "Bank insolvency risk and aggregate Z-score measures: a caveat", Economics Bulletin, Vol. 30 No. 4, pp. 2576-2578.

Sufian, F. (2007), "Mergers and acquisitions in the Malaysian banking industry: technical and scale efficiency effects", International Journal of Financial Services Management, Vol. 2 No. 4, pp. 304-326.

Sufian, F. and Habibullah, M.S. (2010), "Does economic freedom fosters banks' performance? Panel evidence from Malaysia", Journal of Contemporary Accounting \& Economics, Vol. 6 No. 2, pp. 77-91.

Sufian, F. and Hassan, M.K. (2012), "Economic freedom, development and bank intermediation spreads", Southwestern Economic Review, Vol. 39, pp. 1-35.

Sufian, F. and Shah Habibullah, M. (2013), "Financial sector consolidation and competition in Malaysia: an application of the panzar-rosse method", Journal of Economic Studies, Vol. 40 No. 3, pp. 390-410.

Sufian, F. and Zulkhibri, M. (2011), "The Nexus between economic freedom and Islamic Bank performance in the MENA banking sectors", MPRA_paper_51285.pdf.

Sundararajan, V. and Errico, L. (2002), "Islamic financial institutions and products in the global financial system: key issues in risk management and challenges ahead", IMF Working Paper No. WP/02/192, International Monetary Fund, Washington, DC.

Syahirah, S.J. (2018), "Malaysia falls to 79th position on economic freedom index [Blog post]", available at: www.theedgemarkets.com/article/malaysia-falls-79th-position-economic-freedom-index (accessed June 25, 2019).

Vives, X. (2010), “Competition and stability in banking”, Working Paper No. 852, IESE Business School, Navara, April. 
Iqbal, Z. and Mirakhor, A. (2011), An Introduction to Islamic Finance: Theory and Practice, Vol. 687, John Wiley and Sons Ltd, Chichester.

Sarin, N. and Summers, L.H. (2016), "Have big banks gotten safer?", Brookings Papers on Economic Activity, BPEA Conference, Draft, Washington, DC, September 15-16.

Sufian, F. (2014), "The nexus between economic freedom and islamic bank performance: empirical evidence from the MENA banking sectors", Contemporary Review of the Middle East, Vol. 1 No. 4, pp. 411-439.

\section{Corresponding author}

Rafik Harkati can be contacted at: rafikharkati@gmail.com 